\title{
Polyphenols from the extract and fraction of $T$. indica seeds protected HepG2 cells against oxidative stress
}

\author{
Nurhanani Razali', Sarni Mat Junit', Azhar Ariffin², Nur Siti Fatimah Ramli and Azlina Abdul Aziz ${ }^{1 *}$
}

\begin{abstract}
Background: Tamarindus indica L. (T. indica) or locally known as "asam jawa" belongs to the family Leguminosae. T. indica seeds as by-products from the fruits were previously reported to contain high polyphenolic content. However, identification of their bioactive polyphenols using recent technologies is less well researched but nonetheless important. Hence, it was the aim of this study to provide further information on the polyphenolic content and antioxidant activities as well as to identify and quantify its bioactive polyphenols.

Methods: T. indica seeds were extracted with methanol and were then fractionated with different compositions of hexane, ethyl acetate and methanol. Polyphenolic contents were measured using Folin-Ciocalteu assay while antioxidant activities were measured using DPPH radical scavenging and ferric reducing (FRAP) activities. The cytotoxic activities of the crude extract and the active fraction were evaluated in HepG2 cells using MTT assay. The cells were then pre-treated with the $\mathrm{IC}_{20}$ concentrations and induced with $\mathrm{H}_{2} \mathrm{O}_{2}$ before measuring their cellular antioxidant activities including FRAP, DPPH, lipid peroxidation, ROS generation and antioxidant enzymes, SOD, GPx and CAT. Analyses of polyphenols in the crude extract and its active fraction were done using UHPLC and NMR.

Results: Amongst the 7 isolated fractions, fraction F3 showed the highest polyphenolic content and antioxidant activities. When HepG2 cells were treated with fraction F3 or the crude extract, the former demonstrated higher antioxidant activities. F3 also showed stronger inhibition of lipid peroxidation and ROS generation, and enhanced activities of SOD, GPx and CAT of HepG2 cells following $\mathrm{H}_{2} \mathrm{O}_{2}$-induced oxidative damage. UHPLC analyses revealed the presence of catechin, procyanidin B2, caffeic acid, ferulic acid, chloramphenicol, myricetin, morin, quercetin, apigenin and kaempferol, in the crude seed extract of T. indica. UHPLC and NMR analyses identified the presence of caffeic acid in fraction F3. Our studies were the first to report caffeic acid as the active polyphenol isolated from $T$. indica seeds which likely contributed to the potent antioxidant defense system of HepG2 cells.
\end{abstract}

Conclusion: Results from this study indicate that caffeic acid together with other polyphenols in $T$. indica seeds can enhance the antioxidant activities of treated HepG2 cells which can provide protection against oxidative damage.

Keywords: Tamarindus indica seeds, antioxidant, MDA, 4-HNE, flavonoids, polyphenols, UHPLC, NMR, HepG2 cells

\footnotetext{
*Correspondence: azlina_aziz@um.edu.my

'Department of Molecular Medicine, Faculty of Medicine, University of

Malaya, 50603 Kuala Lumpur, Malaysia

Full list of author information is available at the end of the article
} 


\section{Background}

Oxidative damage has been implicated in ageing and many human diseases and disorders including cancer, cardiovascular diseases especially atherosclerosis, diabetes and chronic inflammatory diseases [1]. Antioxidants can delay or inhibit oxidative damage by acting as free radical scavengers, working primarily by donating electrons to the free radicals, thereby deactivating them [2]. Amongst the sources of antioxidants, natural antioxidants from plants have been gaining attention in recent years due to their therapeutic values and fewer biological side effects. Amongst the numerous phytochemicals, polyphenolic compounds have gained popularity due to their reported potent antioxidant activities [3, 4].

Tamarindus indica $L$. (T. indica) or locally known as "asam jawa" is a medicinal plant with high antioxidant activities. The plant belongs to the family Leguminosae and grows indigenously in Africa [5], although it is now cultivated in many tropical countries [6]. The fruit, which is rich in vitamin $C$ and contains tartaric, malic, and citric acids as well as sugars, is the most consumed part of the plant. Due to its sweet-sour taste, the fruit is used as flavoring in cooking. The fruit is used as ingredients in commercialized food products such as drinks, curries, chutneys and also in Worcestershire sauce [7]. On the other hand, tamarind seed is a by-product of the commercial utilization of the fruit. The seeds are also edible and are normally roasted and consumed as pulses [8]. Commercially, tamarind seed is used as raw material for production of tamarind seed gum, for use in industries such as food [9] and medicine, as thickening and stabilizing agent [10, 11]. Scientifically, the aqueous seed extracts of $T$. indica showed potent anti-diabetic and anti-hyperlipidemic activities in streptozotocin (STZ)-induced male rats [12].

Our group had initially reported that the methanol extracts of $T$. indica seed, leaf, leaf veins and skin contained considerable polyphenolic content and antioxidant activities [13]. Amongst these extracts, the methanol seed extract of $T$. indica showed higher polyphenolic content and more potent antioxidant activities. However, this study was performed in the crude extracts which contained mixtures of the polyphenolic antioxidants. As such, the bioactive compounds, particularly the polyphenols, responsible for the antioxidant activities have not been thoroughly researched. In view of this limited data, it was the aim of this study to perform bioactivityguided fractionation of the crude methanol seed extract of $T$. indica and to identify the bioactive compounds using chromatographic and spectroscopic techniques.

\section{Methods}

\section{Chemicals}

Solvents used for extraction of plant samples were purchased from Fisher Scientific. The polyphenolic standards were of HPLC grade (purity >99\%) and were obtained from Sigma. Water used was of Millipore quality. The human liver HepG2 cell lines were purchased from American Type Culture Collection (ATCC), USA. The growth medium, serum and antibiotics for the cell culture experiments were purchased from Flowlab, Australia. All other reagents used in the experiments were of analytical grade and obtained mostly from Fluka and Sigma.

\section{Extraction and fractionation of the crude methanol seed extract of $T$. indica}

$T$. indica plants were collected from Kedah in the northern region of Malaysia. The voucher specimen of the plant (ID no.: KLU 45976) was deposited in the Rimba Ilmu Herbarium, University of Malaya. The dried and powdered seeds of $T$. indica were extracted with methanol at room temperature for $24 \mathrm{~h}$ with a mass to volume ratio of $1: 20(\mathrm{~g} / \mathrm{ml})$ [13]. The methanol extract was evaporated under reduced pressure and the residues were dissolved in $10 \%$ DMSO. The two solvents, methanol and DMSO were non-toxic at concentrations that were used to dissolve the plant extracts. Extracts were kept at $-20{ }^{\circ} \mathrm{C}$ until further analyses.

The methanol seed extract of $T$. indica was subjected to silica gel column chromatography $(0.063-0.200 \mathrm{~mm})$ (Merck) and eluted with hexane:ethyl acetate (90:10), (70:30), (50:50), (25:75), (0:100) and ethyl acetate:methanol (25:75), (50:50), (75:25), (0:100), successively. Thirty fractions were subsequently combined into seven subfractions according to TLC behaviour when developed using various proportions of ethyl acetate and methanol as the mobile phase. The spots on the TLC sheet were visualized under UV lamp (CAMAG UV, NC, USA) in short wavelength $(254 \mathrm{~nm})$ and long wavelength $(360 \mathrm{~nm})$.

\section{Analyses for polyphenolic content}

Polyphenolic content of the fractions was assessed using the Folin-Ciocalteu assay, employing gallic acid as the standard [14]. Folin-Ciocalteu reagent (1:10) was added to the plant extracts or standard, mixed and incubated for $5 \mathrm{~min}$ at room temperature before the addition of $0.115 \mathrm{mg} / \mathrm{ml}$ of $\mathrm{Na}_{2} \mathrm{CO}_{3}$. The mixture was incubated for $2 \mathrm{~h}$ before absorbance readings were taken at $765 \mathrm{~nm}$. Results obtained were expressed as mg gallic acid equivalents (GAE)/g dried plant material.

\section{Ferric reducing activity}

The ferric reducing activity of the plant extracts was estimated based on the FRAP assay developed by Benzie and Strain (1996) [15].

Reagents for this assay consisted of $300 \mathrm{mmol} / \mathrm{l}$ acetate buffer (pH 3.6), $10 \mathrm{mmol} / \mathrm{l}$ 2,4,6-tri(2-pyridyl)-S-triazine (TPTZ) in $40 \mathrm{mmol} / \mathrm{l}$ of $\mathrm{HCl}$ and $20 \mathrm{mmol} / \mathrm{l}$ 
$\mathrm{FeCl}_{3} \cdot 6 \mathrm{H}_{2} \mathrm{O}$. FRAP reagent was prepared fresh by mixing the respective reagents in a ratio of 10:1:1. The assay was performed by initially incubating the FRAP reagent at $37^{\circ} \mathrm{C}$ for $5 \mathrm{~min}$ and subsequently taking a blank reading at $593 \mathrm{~nm}$. Thereafter, $30 \mu \mathrm{l}$ of plant extracts or standard along with $90 \mu \mathrm{l}$ of distilled water was added to $900 \mu \mathrm{l}$ of FRAP reagent. Absorbance readings were recorded immediately upon addition of the FRAP reagent and after 4 min of reaction. $\mathrm{FeSO}_{4}$ was used as the standard and was tested in parallel.

\section{DPPH radical scavenging activity}

The scavenging activity of the free radical, 2,2-diphenyll-picrylhydrazyl (DPPH) was determined by the method described by Braca et al. (2001) [16]. A series of concentrations of the plant extracts were added to DPPH solution $(0.04 \mathrm{mg} / \mathrm{ml})$. After a $20 \mathrm{~min}$ incubation period, absorbance was read at $517 \mathrm{~nm}$. Radical scavenging activity against DPPH was expressed as percentage of inhibition and this was calculated according to the following formula:

$$
\begin{aligned}
& \text { Percentage of inhibition }(\%) \\
& \quad=\frac{[\text { OD control - OD sample }]}{\text { OD control }} \times 100 \%, \text { where OD } \\
& =\text { Optical Density }
\end{aligned}
$$

Using the percentage of inhibition values, a doseresponse curve was plotted, from which the $\mathrm{IC}_{50}$ value was extrapolated. The antioxidant activity was expressed as $\mathrm{IC}_{50}$ value which was the concentration $(\mu \mathrm{g} / \mathrm{ml})$ that inhibited the DPPH radicals by $50 \%$. From the polyphenolic content and antioxidant analyses, the most active fraction was identified and was subjected to cell culture treatments.

\section{Analyses of antioxidant activities in HepG2 cells treated with the antioxidant-rich crude and fractionated seed ex- tracts of $T$. indica \\ Cytotoxicity assay}

The human liver HepG2 cells were grown in Dulbecco's modified Eagle's medium (DMEM) supplemented with $10 \%$ fetal bovine serum, $1 \%$ penicillin and $1 \%$ streptomycin. Cells were maintained in humidified air with $5 \%$ $\mathrm{CO}_{2}$ at $37^{\circ} \mathrm{C}$.

A cytotoxicity assay was then carried out using 3-(4,5dimethylthiazol-2-yl)-2,5-diphenyltetrazolium bromide (MTT) as described by Mosmann (1983), with minor modifications. HepG2 at a density of 5000 cells per well were seeded in a 96-well ELISA microplate and incubated at $37^{\circ} \mathrm{C}$ in $5 \% \mathrm{CO}_{2}$ for $24 \mathrm{~h}$. After $24 \mathrm{~h}$, plant extracts, at various concentrations ranging from 0 to $200 \mu \mathrm{g} / \mathrm{ml}$, were added into the wells. The cells were left to grow in the incubator for $48 \mathrm{~h}$. After $48 \mathrm{~h}$, MTT reagent was added and the mixture was further incubated for $4 \mathrm{~h}$. Then, the mixture in each well was removed and formazan crystals formed were dissolved in $75 \%$ isopropanol. Spectrophotometry measurement of the mixture was performed using a microplate-reader (Bio-Rad) at wavelengths of 570 and $620 \mathrm{~nm}$. A log plot of cell viability (\%) against the concentrations of plant extracts was constructed with the final concentration ranging from 0 to $200 \mu \mathrm{g} / \mathrm{ml}$. From the plot, the final concentration of the plant extracts that reduced cell viability by $50 \%\left(\mathrm{IC}_{50}\right)$ was calculated. The relatively nontoxic $\mathrm{IC}_{20}$ concentration where the HepG2 cells showed more than $80 \%$ viability was also calculated. This concentration $\left(\mathrm{IC}_{20}\right)$ was selected for further treatment in HepG2 cells.

\section{Treatment of HepG2 cells with the crude methanol and fractionated seed extracts of $T$. indica}

Confluent $(85-90 \%)$ HepG2 cells $\left(1 \times 10^{6}\right.$ cells $)$, which were maintained in DMEM, were treated with the antioxidant-rich crude and fractionated extracts of $T$. indica seeds at $\mathrm{IC}_{20}$ concentration, determined from the MTT assay. The cells were incubated with or without the extracts at $37^{\circ} \mathrm{C}$ for $24 \mathrm{~h}$. After $24 \mathrm{~h}$ incubation, the cell lysates were washed with cold PBS and lysed in Tris-Hydrochloride (Tris-HCl) buffer (25 mM, pH 7.4) and subsequently sonicated for $2 \mathrm{~min}$ at $70 \%$ amplitude. The supernatant was used for analyses of antioxidant activities, antioxidant enzymes, lipid peroxidation and ROS levels.

\section{FRAP activity in treated HepG2 cells}

The protocol for FRAP assay measured in HepG2 cells was as described above, with slight modifications [17]. Briefly, $87.5 \mu \mathrm{l}$ of freshly prepared FRAP reagent was added to the cells and the reaction mixture was incubated for $30 \mathrm{~min}$ at $37^{\circ} \mathrm{C}$. Absorbance reading was then taken at $590 \mathrm{~nm}$. $\mathrm{FeSO}_{4} \cdot 7 \mathrm{H}_{2} \mathrm{O}$ was used as standard and was run parallel with the samples.

\section{DPPH radical scavenging activity in treated HepG2 cells}

The DPPH radical scavenging activity was determined following the method described above. Freshly prepared DPPH reagent with a volume of $175 \mu \mathrm{l}$ was added to the cells and absorbance was read at $517 \mathrm{~nm}$ after $20 \mathrm{~min}$. Results were expressed as $\mathrm{IC}_{50}$ of the plant extracts determined from the dose-response curve.

Inhibition of lipid peroxidation and ROS production and activity of antioxidant enzymes in treated HepG2 cells HepG2 cells were seeded and pre-treated with the extracts and fractions following the previously described protocol. After $24 \mathrm{~h}$, oxidative stress was induced in the cells with $1 \mathrm{mM} \mathrm{H} \mathrm{H}_{2} \mathrm{O}_{2}$ for $2 \mathrm{~h}$. Untreated cells induced 
with $\mathrm{H}_{2} \mathrm{O}_{2}$ acted as control. The cells were subsequently washed with ice-cold PBS and detached using a scraper. Cells were then collected into a microtube and centrifuged for $10 \mathrm{~min}$ at $8000 \times \mathrm{g}$ at $4{ }^{\circ} \mathrm{C}$. The supernatant was discarded and the cell pellets were lysed in Tris- $\mathrm{HCl}$ buffer ( $25 \mathrm{mM}, \mathrm{pH}$ 7.4) followed by sonication for $5 \mathrm{~min}$ at $60 \%$ amplitude. Protein content of each sample was quantified using Bradford assay, employing bovine serum albumin (BSA) as the standard. One hundred $\mu \mathrm{g} /$ $\mathrm{ml}$ of protein was used in the lipid peroxidation and antioxidant enzyme assays.

\section{Bradford protein assay}

Protein concentration was estimated using Bradford Protein Assay Kit I (Bio-Rad, USA) with Bovine Serum Albumin (BSA) as the standard. Briefly, the BSA stock ( $2 \mathrm{mg} / \mathrm{ml}$ ) was diluted to $1 \mathrm{mg} / \mathrm{ml}$. Two hundred microlitres of Bradford dye reagent was pipetted into each well of a 96-well dish. The diluted BSA stock was added to the wells to give a final concentration within the range of $0.2 \mathrm{l}-1 \mathrm{mg} / \mathrm{ml}$. One microlitre of sample was then added to the wells and absorbance was read at $595 \mathrm{~nm}$ after $5 \mathrm{~min}$ incubation at room temperature. A BSA standard curve was generated for estimation of protein concentration of the samples. Samples corresponding to $100 \mu \mathrm{g} / \mathrm{ml}$ of protein were subsequently aliquoted into microcentrifuge tubes for the lipid peroxidation and antioxidant enzyme assays.

\section{Inhibition of lipid peroxidation}

Levels of lipid peroxidation in the treated cells were determined by measuring the production of malondialdehyde (MDA) in the presence of thiobarbituric acid (TBA) [18]. The TBA reagent used in this assay consisted of a mixture of TBA, trichloroacetic acid (TCA) and $70 \%$ perchloric acid $\left(\mathrm{HClO}_{4}\right)$ in distilled water. Tetraethoxypropane (TEP) in ethanol was used as the standard. TBA reagent was added to the sample or standard and boiled for $20 \mathrm{~min}$. The mixture was left to cool and was centrifuged for $10 \mathrm{~min}$ at $960 \times \mathrm{g}$ at $25^{\circ} \mathrm{C}$. The supernatant was pipetted into a 96-well plate and absorbance was measured at $532 \mathrm{~nm}$ on a microplate reader. The amount of MDA in the treated and untreated samples was determined using the equation obtained from the standard curve of TEP. Results were expressed as nmol MDA equivalents/mg of protein.

The abundance of 4-hydroxynonenal (4-HNE) protein adducts in both untreated and treated cells were also measured using ELISA kit to analyse the effect of the crude extract and fraction F3 of $T$. indica seeds in inhibiting lipid peroxidation in HepG2 cells. Supernatants were collected from each sample and the abundance of proteins were detected against 4-HNE (QY-E05206) according to the manufacturers' protocols (Shanghai
Qayee, China). Briefly, $10 \mu \mathrm{l}$ of samples were pipetted into a pre-coated ELISA microplate, followed by the addition of HRP conjugate for detection. The plate was washed to remove unbound substances and the endproduct was measured at $450 \mathrm{~nm}$. A known HNE-BSA standard curve was constructed to determine the concentration of 4-HNE protein adducts present in the samples.

\section{Assay for reactive oxygen species (ROS)}

ROS production was assessed using the method of Wang and Joseph (1999) with minor modifications [19]. HepG2 cells were plated into black 96-well plates, seeded and treated as previously described. At the end of the treatment, the medium was removed and the cells were washed with PBS and then incubated with $100 \mathrm{mM}$ dichlorofluorescein diacetate (DCF-DA) in PBS for $30 \mathrm{~min}$ at $37{ }^{\circ} \mathrm{C}$. The formation of the fluorescentoxidized derivatives of DCF-DA was monitored at emission wavelength of $530 \mathrm{~nm}$ and excitation wavelength of $485 \mathrm{~nm}$ in a fluorescence multi-detection reader (Synergy HTTM Multi-detection microplate reader; BioTek Instruments Inc, VT, USA). ROS production was expressed as relative fluorescence unit (RFU) produced by DCF-DA/mg of total protein [20].

\section{Antioxidant enzyme assays}

The antioxidant enzymes tested were superoxide dismutase (SOD), catalase (CAT) and glutathione peroxidase (GPx). All three enzyme activities were measured using assay kits from Cayman Chemicals (USA), following the manufacturer's instructions.

SOD assay utilizes tetrazolium salt for detection of superoxide radicals generated by xanthine oxidase and hypoxanthine. The SOD activities were estimated colorimetrically at a wavelength of $450 \mathrm{~nm}$. SOD activities were expressed as Unit/mL, following the manufacturer's protocol, whereby one unit is defined as the amount of enzyme needed to exhibit $50 \%$ dismutation of the superoxide radicals per $\mathrm{ml}$ of reaction volume (Unit/ $\mathrm{mL})$.

CAT assay measures the reaction of CAT in the presence of an optimal concentration of $\mathrm{H}_{2} \mathrm{O}_{2}$. The reaction produced formaldehyde, which was measured colorimetrically with 4-amino-3-hydrazino-5-mercapto-1,2,4-triazole (Purpald) as the chromogen. Purpald specifically forms a bicyclic heterocycle with aldehydes, which upon oxidation changes from colorless to purple. The formaldehyde concentration in the cells was measured using the equation obtained from the linear regression of the standard curve. CAT activities in the samples were expressed in $\mathrm{nmol} \mathrm{H}_{2} \mathrm{O}_{2}$ oxidized/min/ml.

GPx activity was measured through a coupled reaction with glutathione reductase whereby GPx catalyzed the 
reduction of hydroperoxides, including $\mathrm{H}_{2} \mathrm{O}_{2}$ by reduced glutathione, which led to the protection of cells from oxidative damage. GPx activities in the cells were initially calculated by determining the changes in absorbance per minute obtained from the standard curve of GPx control. One unit of activity is defined as the amount of enzyme that caused the oxidation of $1.0 \mathrm{nmol}$ of $\mathrm{NADPH}$ to $\mathrm{NADP}^{+}$per minute per $\mathrm{ml}$ of sample $(\mathrm{nmol} / \mathrm{min} / \mathrm{ml})$ at room temperature.

\section{Analysis of polyphenols using ultra high performance liquid chromatography (UHPLC) Preparation of samples}

The crude and fractionated seed extracts of $T$. indica were subjected to acid hydrolysis prior to analysis by UHPLC to release glycosides from the conjugated polyphenols [21]. The dried powder of $T$. indica leaf and its fraction were mixed with $1.2 \mathrm{M} \mathrm{HCl}$ in $50 \%$ aqueous methanol containing $20 \mathrm{mM}$ sodium diethyldithiocarbamate as an antioxidant. The mixture was heated at $90{ }^{\circ} \mathrm{C}$ for $2 \mathrm{~h}$ using a heating block with stirring capacity (Reacti-Therm, Pierce, Rockford, USA). Aliquots of the samples were taken after the hydrolysis, centrifuged for $5 \mathrm{~min}$ at $5000 \times \mathrm{g}$ and diluted with distilled water $(\mathrm{pH}$ 2.6). The hydrolysate was then filtered through a $0.20 \mu \mathrm{m}$ polytetrafluoroethylene (PTFE) membrane filter prior to analysis by UHPLC.

Analyses of polyphenols were conducted using an UHPLC 1290 Infinity LC system (Agilent Technologies, Waldbronn, Germany) equipped with a binary pump, diode array detector and an auto sampler. Separation of polyphenols was achieved using a ZORBAX Eclipse Plus $\mathrm{C}_{18}$ column $(50 \times 2.1 \mathrm{~mm}, 1.8 \mu \mathrm{m})$ (Agilent, Germany), with temperature of the auto sampler set at $10{ }^{\circ} \mathrm{C}$. Three microlitres of the sample were injected into the system. The mobile phase consisted of water containing $0.1 \%$ trifluoroacetic acid (TFA), pH 2.6 (solvent A) and methanol (solvent B). Optimum separation was achieved using a constant flow rate of $0.4 \mathrm{~mL} / \mathrm{min}$ and maximum back pressure of $4.000 \mathrm{psi}$, with the following gradient: 95 to $85 \% \mathrm{~A}$ in $2 \mathrm{~min}, 85$ to $75 \% \mathrm{~A}$ in $1 \mathrm{~min}, 75$ to $40 \% \mathrm{~A}$ in $1 \mathrm{~min}, 40$ to $0 \% \mathrm{~A}$ in $0.2 \mathrm{~min}, 0 \% \mathrm{~A}$ in $0.6 \mathrm{~min}$, and 0 to $95 \% \mathrm{~A}$ in $0.2 \mathrm{~min}$, followed by a reequilibration time of $2 \mathrm{~min}$. The polyphenols were detected at 254, 280 and $325 \mathrm{~nm}$ on a diode array detector. Concentration of the polyphenolic compounds in the sample was estimated based on the standard curve generated from pure polyphenolic standards ran under the same conditions as described above.

\section{Identification of polyphenolic compounds in fraction F3 using Nuclear Magnetic Resonance (NMR)}

Fraction F3 was initially concentrated and vacuum-dried using a SpeedVac (Thermo Scientific, DE, USA). Fifteen milligrams of the powder was dissolved in $0.7 \mathrm{~mL}$ of methanol- $\mathrm{d}_{4}$ in a $5 \mathrm{~mm}$ NMR tube for NMR spectra analyses.

NMR spectra were generated from JNM Lambda$400 \mathrm{MHz}$ FT-NMR and ECA-400 FT-NMR spectrometer (Jeol, USA), at ambient temperature. Methanol- $\mathrm{d}_{4}$ was used as a solvent with tetramethylsilane (TMS) as the internal standard. All spectra were reported in units of ppm on the scale, relative to TMS $(\delta 0.00)$ and the coupling constants are given in Hz. Structure elucidation of the bioactive compound was based on ${ }^{1} \mathrm{H}$ NMR, ${ }^{13} \mathrm{C}$ NMR, H-H Correlation Spectroscopy (H-H COSY), Distortionless Enhancement of Polarization Transfer using a $135^{\circ}$ decoupler pulse (DEPT-135) and Heteronuclear Single Quantum Coherence (HSQC) using ACD/NMR Processor Academic Edition software (ACD Labs, Toronto, Canada) [22].

\section{Statistical analyses}

All analyses were done in triplicate. Results were expressed as means \pm standard deviation. The data were statistically analyzed using SPSS statistical software for Windows, Version 21.0. (Armonk, NY: IBM Corp.) An independent $\mathrm{t}$-test was used for comparisons of means between groups. One-way analysis of variance (ANOVA) and Tukey's Honestly Significant Difference test were used to compare means among groups. Pearson correlation coefficient was used to determine the relationship between polyphenolic content in the plant extracts with the respective antioxidant activities. The level of significance was set at $p<0.05$.

\section{Results}

Yield, polyphenolic content and antioxidant activities of the crude and fractions

Table 1 shows the extraction yield of the fractions isolated from the methanol seed extract of $T$. indica, which ranged from 8 to $210 \mathrm{mg} / \mathrm{g}$ dried weight. Amongst all the fractions, fraction 3 (F3) had the highest yield while fraction 6 (F6) had the least. Amongst the seven fractions, fraction F3 contained the highest polyphenolic content $(572 \pm 3.78 \mathrm{GAE} \mathrm{mg} / \mathrm{g})$, followed by F2 (445 \pm $3.97 \mathrm{GAE} \mathrm{mg} / \mathrm{g}$ ) (Table 1). Both F3 and F2 had higher polyphenolic content than the crude extract. F3 also showed the most potent ferric reducing and DPPH radical scavenging activities. DPPH radical scavenging activity, expressed as $\mathrm{IC}_{50}$ could only be detected in fraction $\mathrm{F} 2$ and F3. F3 had even lower $\mathrm{IC}_{50}$ value than the crude extract. Fractions 5, 6, and 7 had very low polyphenolic content $(<20 \mathrm{mg}$ GAE/G) and antioxidant activities whereby ferric reducing activities were not detected in all three extracts. 
Table 1 Yield, polyphenolic content and antioxidant activities of the crude methanol seed extract of T. indica and the corresponding fractions

\begin{tabular}{lllll}
\hline Extracts & Yield (mg/g dried weight) & $\begin{array}{l}\text { Polyphenolic content } \\
(\mathrm{GAE} \mathrm{mg/g})\end{array}$ & $\begin{array}{l}\text { Ferric reducing activity } \\
(\mathrm{mmol} / \mathrm{g} \text { dried weight })\end{array}$ & $\begin{array}{l}\text { DPPH・ radical scavenging activity } \\
\left(\mathrm{IC}_{50} \text { in } \mu \mathrm{g} / \mathrm{ml}\right)\end{array}$ \\
\hline $\begin{array}{l}\text { Crude } \\
\text { Seeds }\end{array}$ & 240.72 & $271.23 \pm 4.78^{\mathrm{a}}$ & $1.45 \pm 0.018^{\mathrm{a}}$ & $50.23 \pm 0.37^{\mathrm{a}}$ \\
Fraction & & & & $\mathrm{ND}$ \\
1 & 20.80 & $84.25 \pm 12.38^{\mathrm{b}}$ & $0.52 \pm 0.003^{\mathrm{b}}$ & $60.76 \pm 0.45^{\mathrm{b}}$ \\
2 & 107.28 & $444.57 \pm 3.97^{\mathrm{c}}$ & $2.30 \pm 0.001^{\mathrm{c}}$ & $42.31 \pm 0.32^{\mathrm{c}}$ \\
3 & 209.52 & $571.71 \pm 3.78^{\mathrm{d}}$ & $5.50 \pm 0.01^{\mathrm{d}}$ & $\mathrm{ND}$ \\
4 & 56.60 & $141.81 \pm 4.59^{\mathrm{e}}$ & $1.08 \pm 0.01^{\mathrm{e}}$ & $\mathrm{ND}$ \\
5 & 10.13 & $15.58 \pm 1.03^{\mathrm{f}}$ & $\mathrm{ND}$ & $\mathrm{ND}$ \\
6 & 6.76 & $10.38 \pm 0.60^{\mathrm{g}}$ & $\mathrm{ND}$ & $\mathrm{ND}$ \\
\hline
\end{tabular}

a-h Values not sharing the same superscript lowercase letter within the same column are significantly different at $p<0.01$ Results are average of triplicate analyses \pm S.D

ND not detected

\section{Correlation analyses}

Pearson correlation analyses were performed to assess the relationship between the polyphenolic content of the isolated fractions and their respective antioxidant activities. A strong positive correlation was observed between polyphenolic content and DPPH radical scavenging activity $\left(\mathrm{R}^{2}=0.951\right)$ and with ferric reducing activity $\left(\mathrm{R}^{2}=\right.$ $0.911)(p<0.05)$. Hence, the polyphenolic content of the fractions contributed significantly to their antioxidant properties.

\section{Cytotoxicity and antioxidant analyses in HepG2 cells Cytotoxicity}

The cytotoxic effects of the crude methanol seed extract and fraction F3 on HepG2 cells were expressed as $\mathrm{IC}_{50}$ (Table 2), which signify the concentration of the plant extracts needed to inhibit $50 \%$ of cell viability after $24 \mathrm{~h}$ of treatment. Following fractionation of the crude extract, F3 exhibited higher cytotoxic effects on HepG2 cells with an $\mathrm{IC}_{50}$ of $50.63 \pm 0.21 \mu \mathrm{g} / \mathrm{ml}$ as compared to the crude seed extract $\left(\mathrm{IC}_{50}=104.71 \pm 0.07\right)$. The nontoxic $\mathrm{IC}_{20}$ concentration where the HepG2 cells showed more than $80 \%$ viability was also calculated. This concentration $\left(\mathrm{IC}_{20}\right)$ was selected for further treatment in HepG2 cells. Figure 1a-d shows the images of the cells viewed under light microscope, when the cells were treated with $\mathrm{IC}_{50}$ and $\mathrm{IC}_{20}$ concentrations of the crude methanol seed extract and fraction F3. Generally, at
$\mathrm{IC}_{20}$, HepG2 cells adhered to the flasks, were spindleshaped with defined cell membranes. However, at $\mathrm{IC}_{50}$, cells were shrunken, clumped together and floated in the medium. The relatively non-toxic $\mathrm{IC}_{20}$ concentration of the extracts of which the HepG2 cells showed more than $80 \%$ viability was then selected for further analyses.

\section{Cellular FRAP and DPPH radical scavenging}

The effects of the crude methanol extracts of seeds and fraction F3 on cellular antioxidant activities in HepG2 cells were determined following treatment of the cells with the $\mathrm{IC}_{20}$ concentration of the extracts.

Untreated HepG2 cells showed very low ferric reducing activity whereas the DPPH radical scavenging activity was undetected. Fractionation of the crude seed extract resulted in higher antioxidant activities (Table 2). F3 showed more potent ferric reducing and DPPH radical scavenging activities in the treated HepG2 cells compared to its crude extracts.

\section{Lipid peroxidation}

$\mathrm{H}_{2} \mathrm{O}_{2}$-induced oxidative damage in the untreated HepG2 cells caused approximately 2 -fold increase in MDA equivalents levels compared to untreated and uninduced cells (Fig. 2a). However, pre-treatment of HepG2 cells with the crude seed extract and F3 caused significant inhibition of lipid peroxidation $(p<0.05)$, with MDA levels being lower than the untreated and uninduced cells. F3

Table 2 Cytotoxic effects and antioxidant activities of the crude methanol seed extract and fraction F3 of T. indica in HepG2 cells

\begin{tabular}{lcccr}
\hline Sample & $I C_{50}$ value $(\mu \mathrm{g} / \mathrm{ml})$ & $I C_{20}$ value $(\mu \mathrm{g} / \mathrm{ml})$ & FRAP $(\mathrm{mmol} / \mathrm{g}$ dried weight) & DPPH $\left(I C_{50}\right.$ in $\left.\mu \mathrm{g} / \mathrm{ml}\right)$ \\
\hline Seed-treated & $104.71 \pm 0.07^{\mathrm{a}}$ & $35.43 \pm 0.08^{\mathrm{a}}$ & $14.41 \pm 0.23^{\mathrm{a}}$ & $40.23 \pm 3.53^{\mathrm{a}}$ \\
F3-treated & $50.63 \pm 0.21^{\mathrm{b}}$ & $12.12 \pm 0.03^{\mathrm{b}}$ & $18.09 \pm 0.54^{\mathrm{b}}$ & $20.89 \pm 2.76^{\mathrm{b}}$
\end{tabular}

a,b Values not sharing the same superscript lowercase letter within the same column were significantly different at $p<0.01$

Results are expressed as average of triplicate analyses \pm S.D 
A
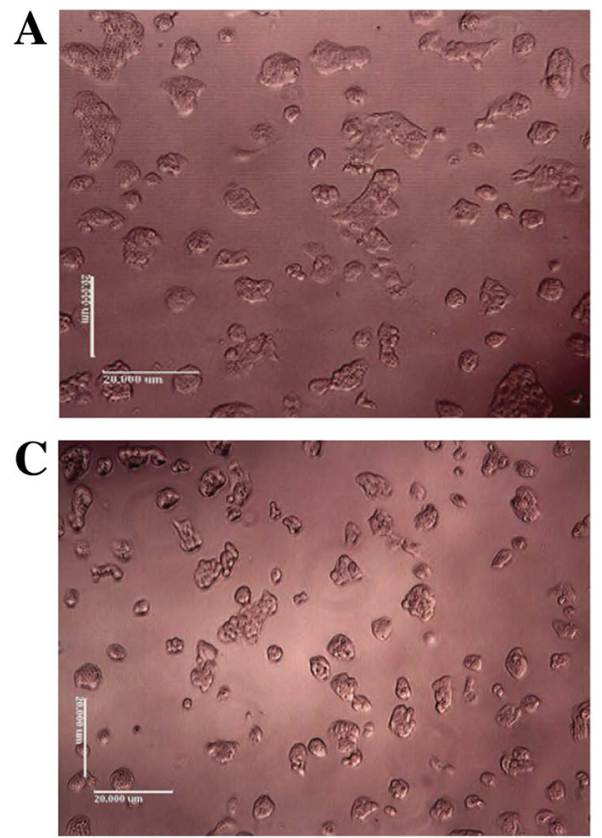

B

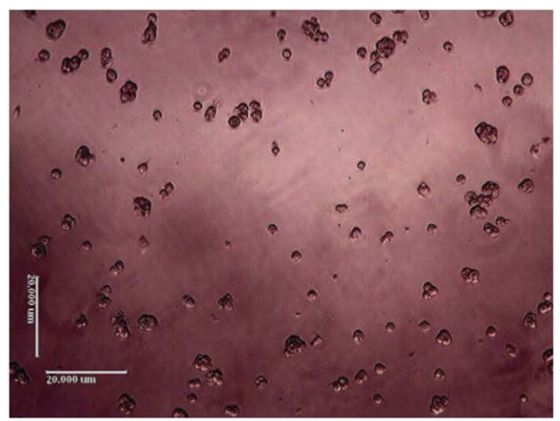

D

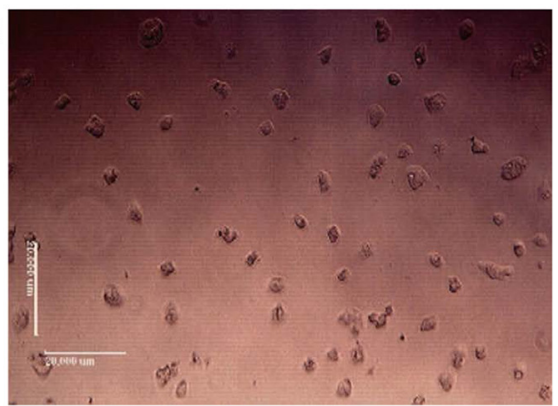

Fig. 1 a-d Morphological changes of HepG2 cells in response to treatment with $I C_{20}$ and $I C_{50}$ concentrations, respectively, of the crude methanol seed extract (a-b), and its active fraction, F3 (c-d). The images were captured using a digital camera attached to an inverted microscope

and its crude seed extract reduced MDA levels by 84 and $79 \%$, respectively, compared to the untreated cells induced with $\mathrm{H}_{2} \mathrm{O}_{2}$.

Figure $2 \mathrm{~b}$ shows the detection of altered abundance of 4-HNE adducts in HepG2 cells treated with the crude seed extract and fraction F3 of T. indica using ELISA analyses. $\mathrm{H}_{2} \mathrm{O}_{2}$-induced HepG2 cells showed approximately 3 -fold increase in levels of 4-HNE compared to untreated and uninduced cells. Pre-treatment of the cells with the crude seed extract led to reduction of 4-HNE levels similar to the untreated, uninduced cells or in the case of fraction F3, even lower than the untreated cells.

\section{ROS production}

The effect of the methanol seed extract and fraction F3 on ROS production was evaluated in HepG2 cells using a cell permeable probe, DCF-DA (Fig. 2c). The fluorescence intensity is proportional to the amount of peroxides, which are produced by the cells. ROS production increased significantly after HepG2 cells were challenged with $1 \mathrm{mM} \mathrm{H}_{2} \mathrm{O}_{2}$ as compared with the untreated and unchallenged cells. However, pre-treatment of the cells with $\mathrm{IC}_{20}$ concentration of the seed extract and fraction F3 significantly decreased $\mathrm{H}_{2} \mathrm{O}_{2}$-mediated ROS formation, whereby intensity of the fluorescence was reduced to a level lower to that of the untreated, $\mathrm{H}_{2} \mathrm{O}_{2}$-challenged cells. Additionally, F3 showed higher inhibition of ROS compared to the crude seed extract $(\mathrm{p}<0.05)$. This can also be observed when ROS production was captured by fluorescence microscopy (Fig. 3a-d).

\section{Antioxidant enzymes}

As shown in Fig. 4a-c, $\mathrm{H}_{2} \mathrm{O}_{2}$-induced oxidative damage in the untreated HepG2 cells caused reduction of all three antioxidant enzymes compared to control untreated cells. However, pre-treatment of HepG2 cells with fraction F3 and the crude extract prior to induction of oxidative damage significantly increased the activities of SOD, GPx and CAT. The increase was higher compared to the untreated cells as well as the untreated $+\mathrm{H}_{2} \mathrm{O}_{2}$ cells. Additionally, F3 showed higher antioxidant enzyme activities compared to the crude seed extract $(p<0.05)$.

\section{Analyses of polyphenols in the methanol seed extract of $T$. indica and fraction F3 using UHPLC}

Figure $5 \mathrm{a}$ shows the chromatogram of a standard mixture of polyphenols analyzed with the UHPLC system. The polyphenols were detected at a wavelength of $280 \mathrm{~nm}$. A satisfactory separation of the polyphenols was obtained using the previously described gradient system and mobile phases.

Figure 5b shows the chromatogram of the polyphenolic profiles in the crude methanol seed extract of T. indica. The chromatogram shows the presence of catechin, procyanidin B2, caffeic acid, ferulic acid, chloramphenicol, myricetin, morin, quercetin, apigenin and kaempferol, detected at $280 \mathrm{~nm}$. When fraction F3 was analyzed on the UHPLC, a single peak was observed and this was later identified as caffeic acid based on comparison with the retention time of caffeic acid standard as 


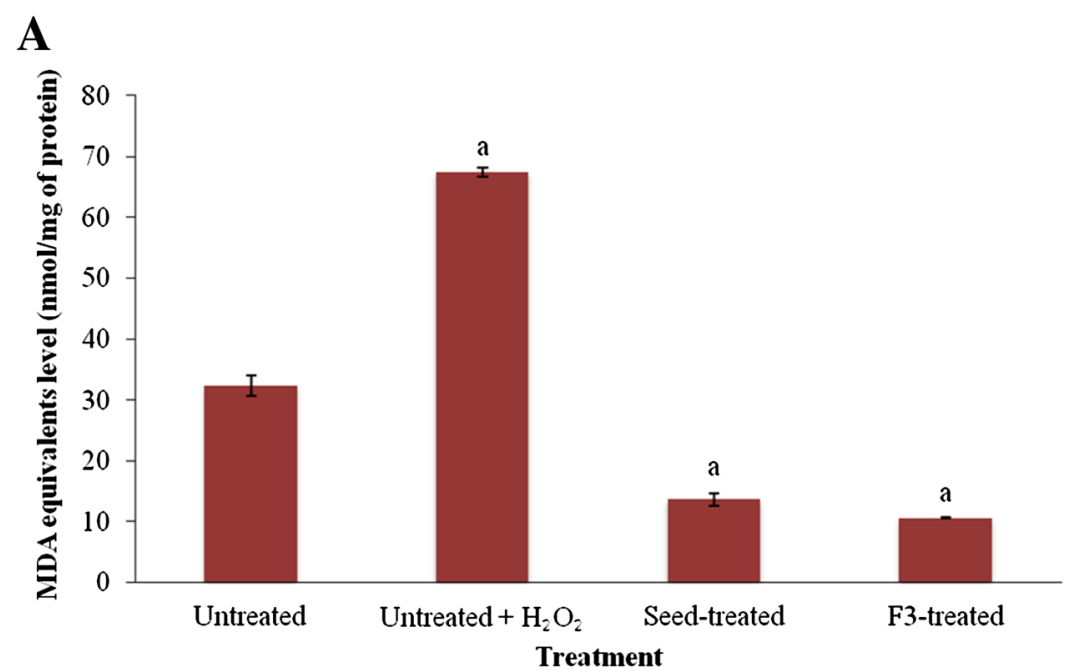

\section{B}

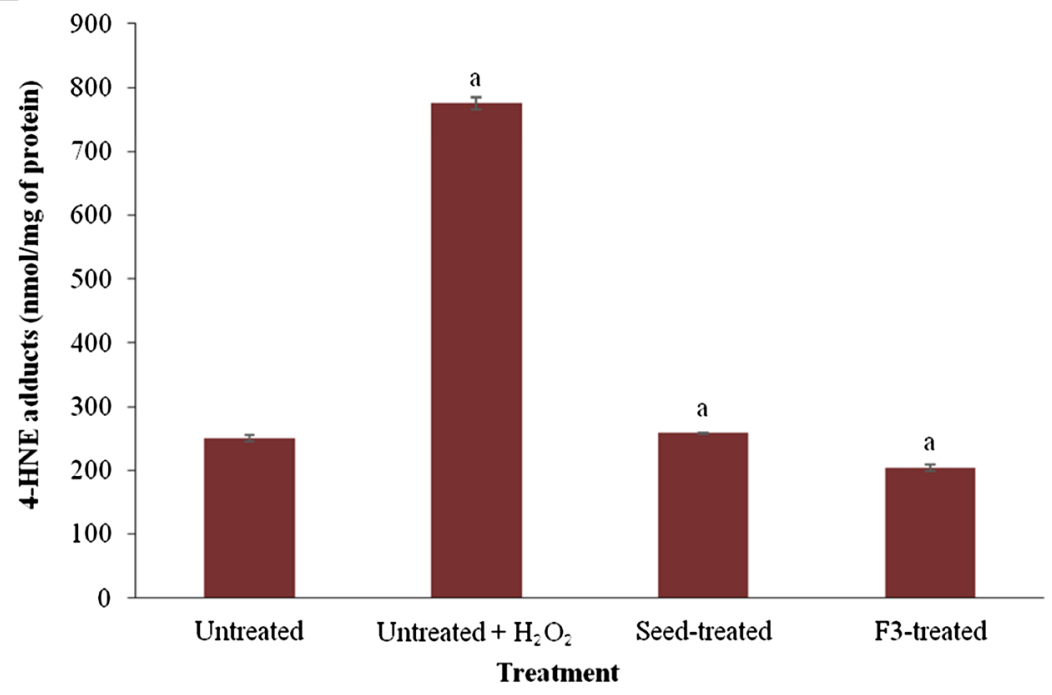

C

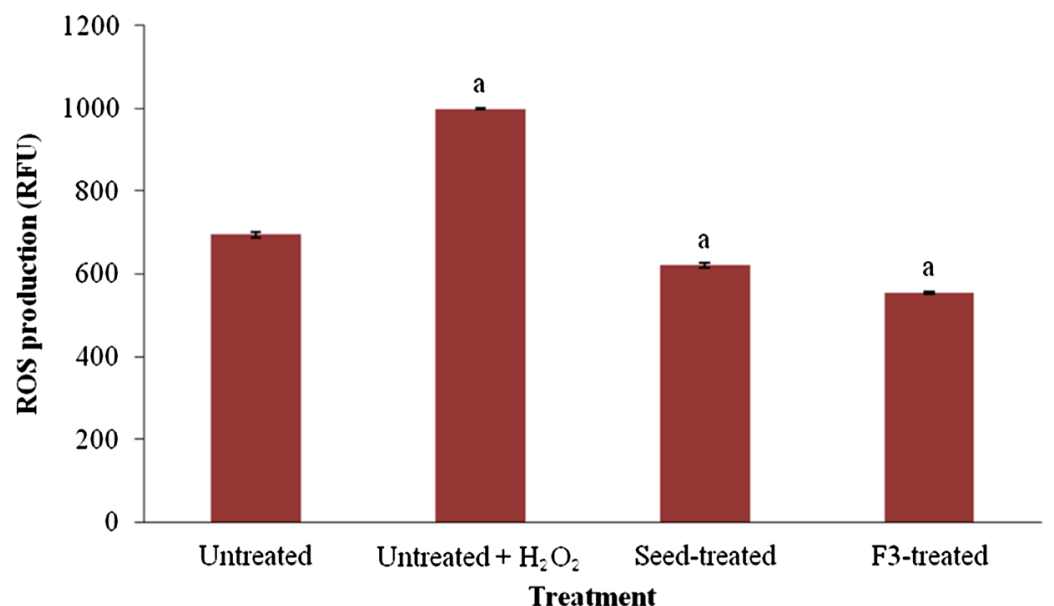

Fig. 2 (See legend on next page.) 
(See figure on previous page.)

Fig. 2 a-c The effects of the crude methanol seed extract and fraction F3 from T. indica, on lipid peroxidation, measured as MDA levels (a) and 4-HNE adducts abundance (b), and inhibition of ROS production (c) in HepG2 cells. Results for MDA levels were expressed as nmol MDA equivalents/mg of protein while 4-HNE levels were expressed as nmol 4-HNE adducts/mg protein. ROS production was measured using fluorescence multi-detection microplate reader and the results were expressed as Relative Fluorescence Unit (RFU). ${ }^{a}$ indicates significant difference from untreated cells $(p<0.05)$. MDA- malondialdehyde; 4-HNE - 4-hydroxynonenal; ROS- reactive oxygen species

well as its absorption spectra on the diode array detector (Fig. 5c).

Quantification of the polyphenols detected in the methanol seed extract of T. indica and F3 is shown in Table 3. The highest amount of polyphenols in the crude extract was procyanidin B2 followed by caffeic acid and myricetin. The crude extract also contained considerable amounts of apigenin, kaempferol and morin, within the range of $70-115 \mu \mathrm{g} / \mathrm{g}$. On the other hand, quercetin showed the lowest content in the crude extract. The content of caffeic acid in fraction F3 is almost similar to that in the crude extract.

\section{Structure elucidation of polyphenol in fraction F3 using NMR}

The compound in fraction F3 appeared as a solid, yellow amorphous. NMR analyses identified caffeic acid as the bioactive compound in fraction F3 further confirming the earlier identification by UHPLC. The structure of bioactive compound in F3 was elucidated using ACD/NMR software based on ${ }^{1} \mathrm{H},{ }^{13} \mathrm{C}, \mathrm{H}-\mathrm{H}$ COSY, DEPT-135 and HSQC (ACD Labs, Toronto, Canada) (Fig. 6a and b).

\section{Discussion}

The present study describes the fractionation of antioxidant-rich methanol seed extract of $T$. indica and the subsequent identification of polyphenols in the crude extracts as well as in fraction F3. We had previously shown that amongst the different aerial parts of the $T$. indica plant, the seeds contained considerable amounts of polyphenolic compounds and antioxidant activities, hence the seeds were chosen for fractionation [13]. Polyphenols are secondary plant metabolites, which are proven to have various biological properties including anti-bacterial, anti-inflammatory and anti-allergic activities [23, 24]. Many of these reported activities can be attributed to the antioxidative properties of the polyphenols [25-27].

Of the seven fractions obtained, only the first four fractions showed significant levels of antioxidant activities and correlation analyses confirmed that the polyphenolic
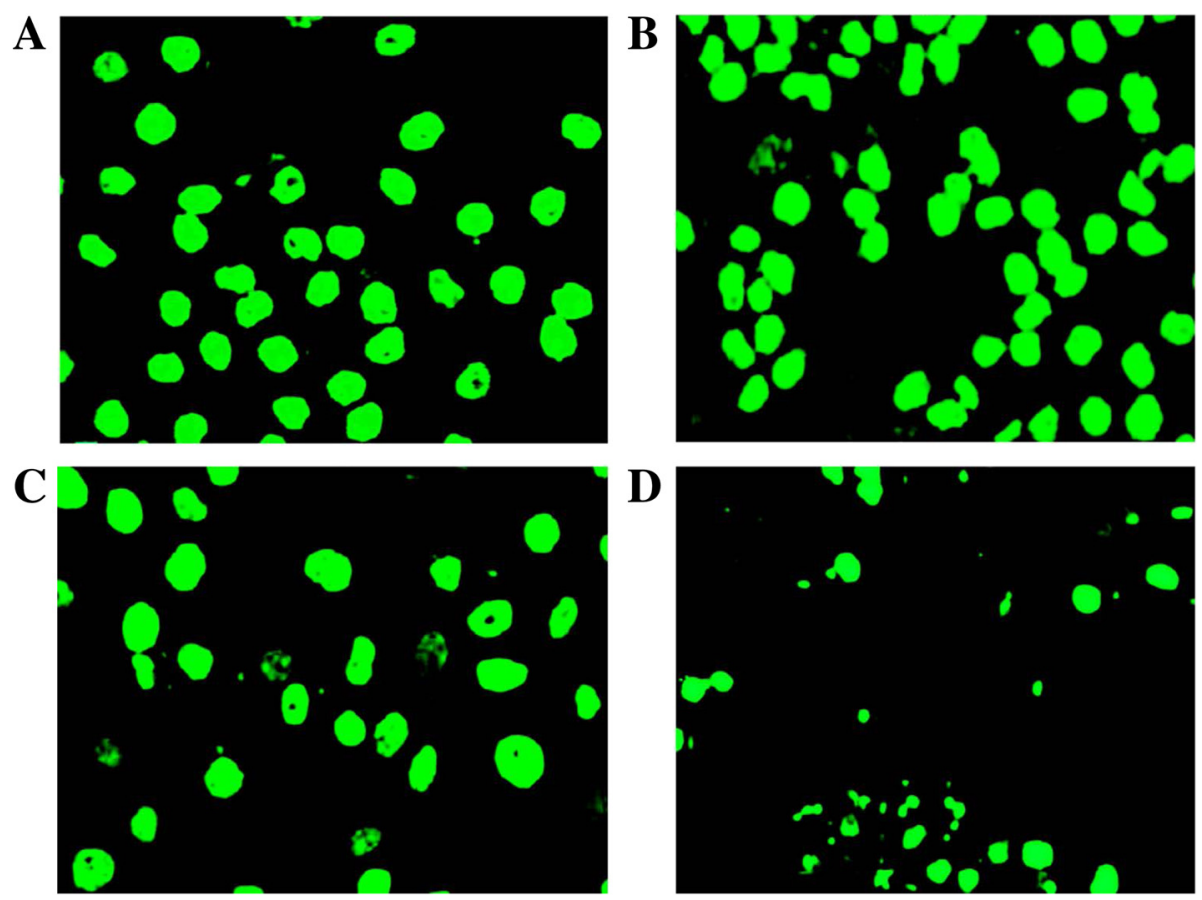

Fig. 3 a-d Image-based ROS measurement captured by fluorescence microscopy in HepG2 cells; a Untreated and uninduced cells, b Untreated and $\mathrm{H}_{2} \mathrm{O}_{2}$-induced cells, c Seed-pre-treated and $\mathrm{H}_{2} \mathrm{O}_{2}$-induced cells and $\mathbf{d}$ F3-pre-treated and $\mathrm{H}_{2} \mathrm{O}_{2}$-induced cells 


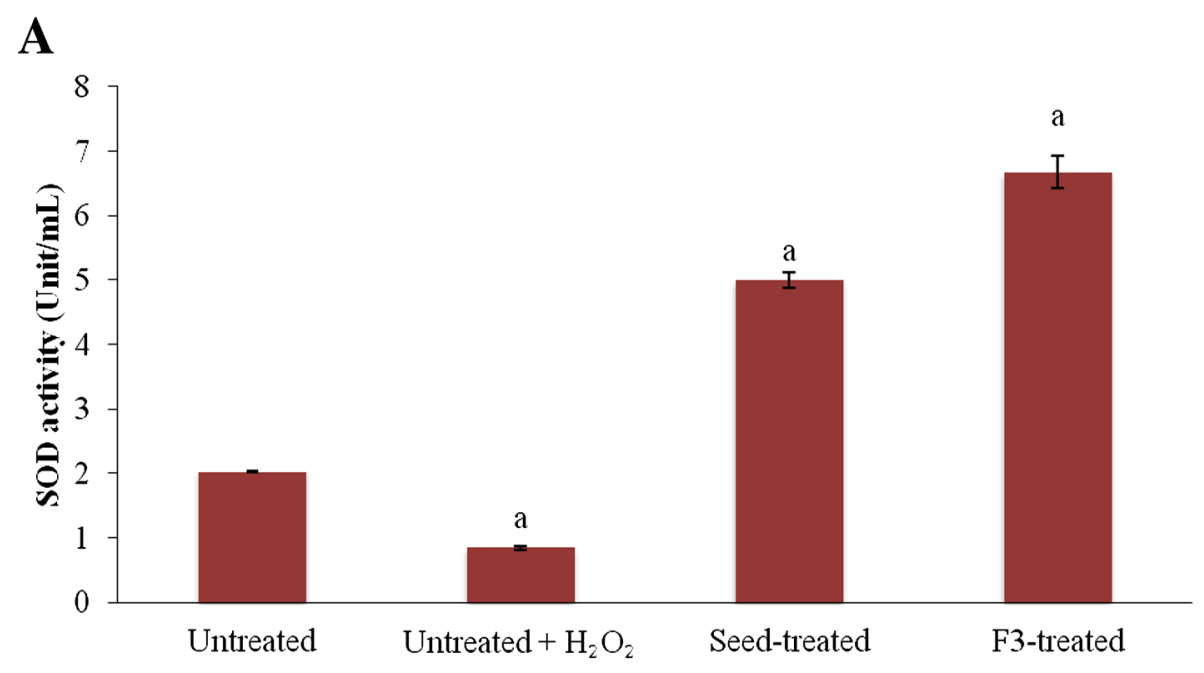

Treatment

\section{B}

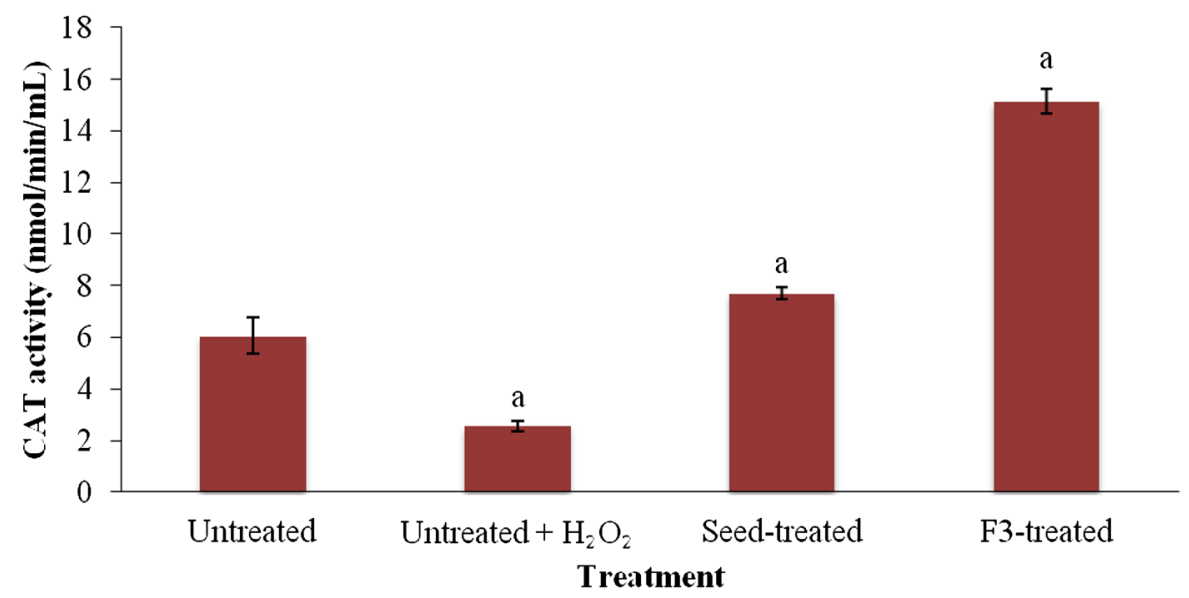

C

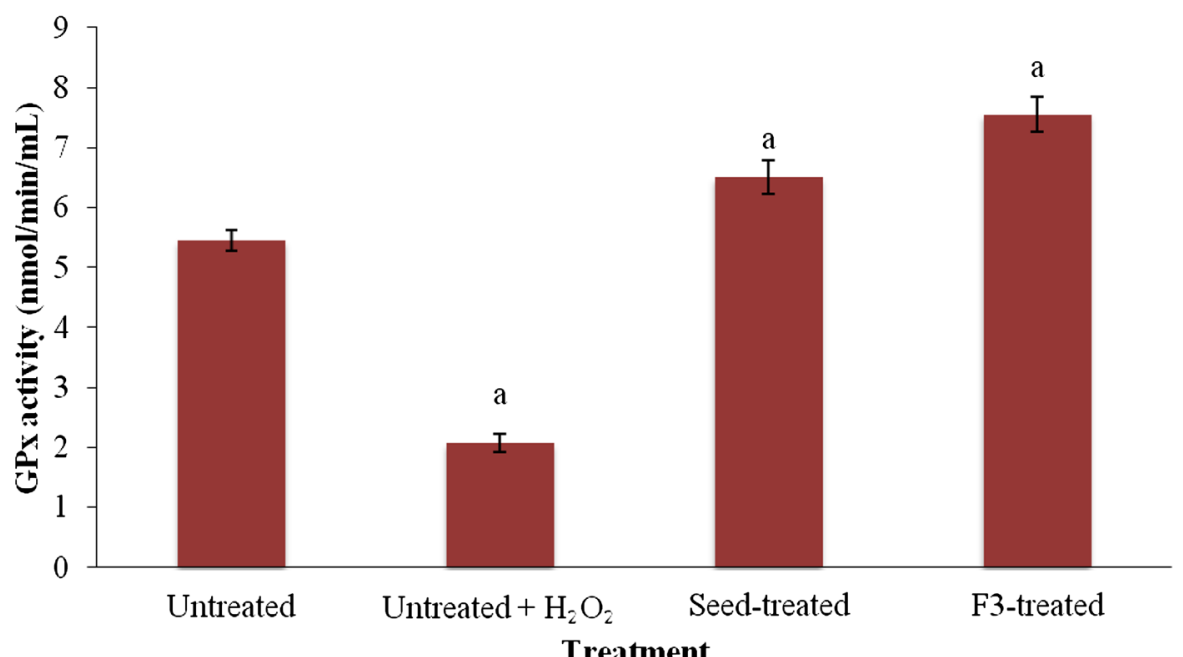

Treatment

Fig. 4 a-c The effects of the crude methanol seed extract and fraction F3 from T. indica on superoxide dismutase (a), catalase (b) and glutathione peroxidase $(\mathbf{c})$ activities. ${ }^{a}$ indicates significant difference from untreated cells $(p<0.05)$. SOD- superoxide dismutase, CAT- catalase, GPXglutathione peroxidase 
A

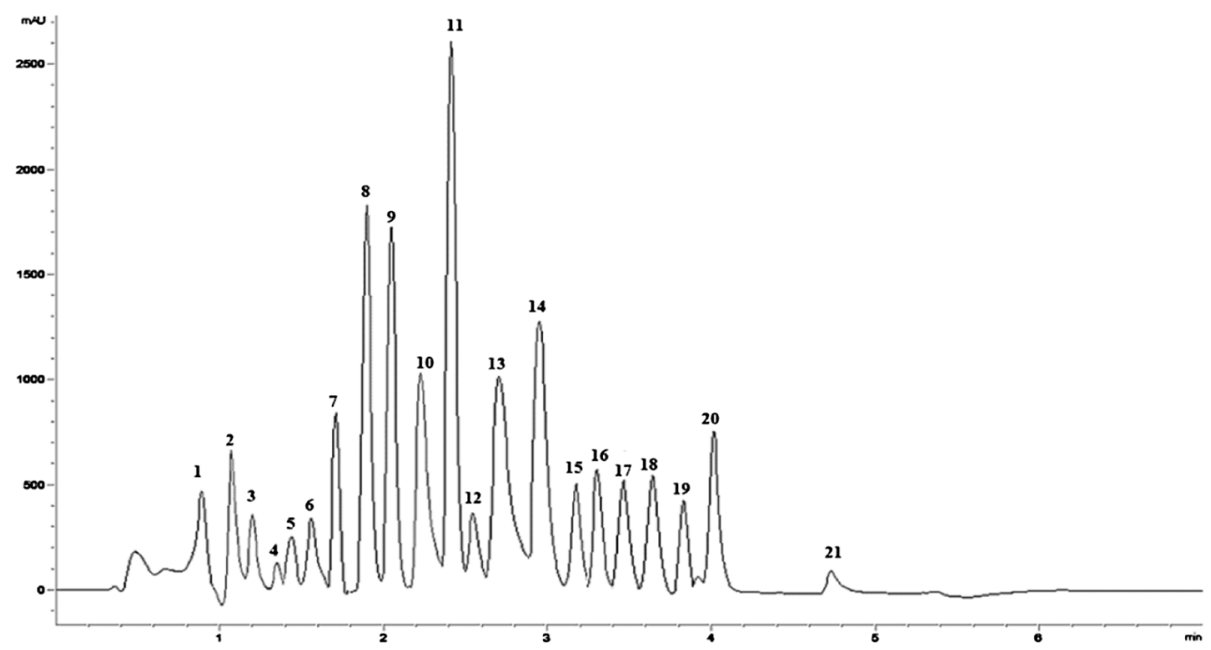

B

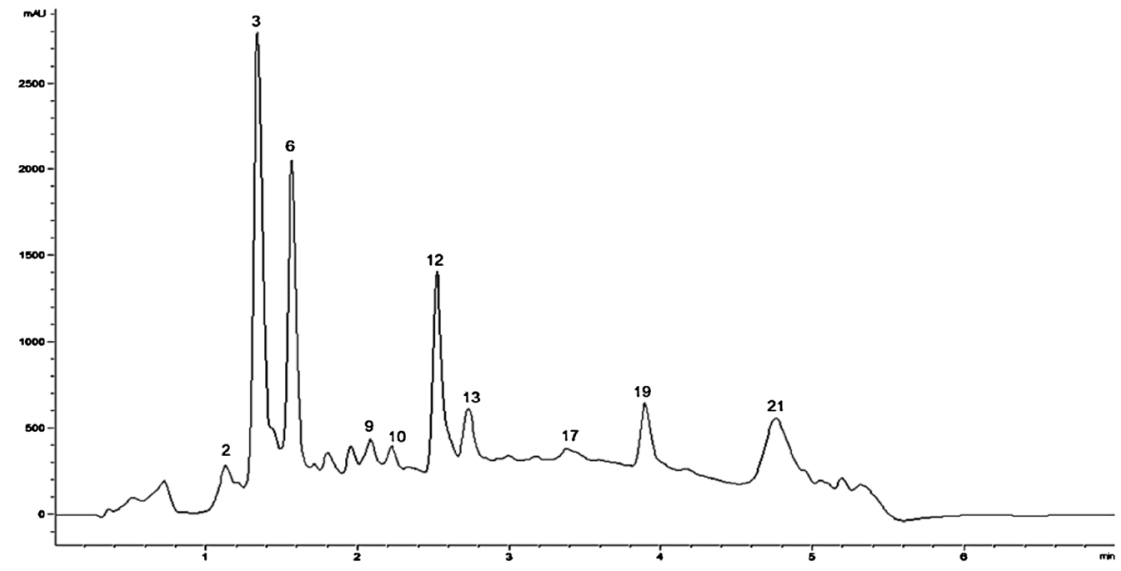

C

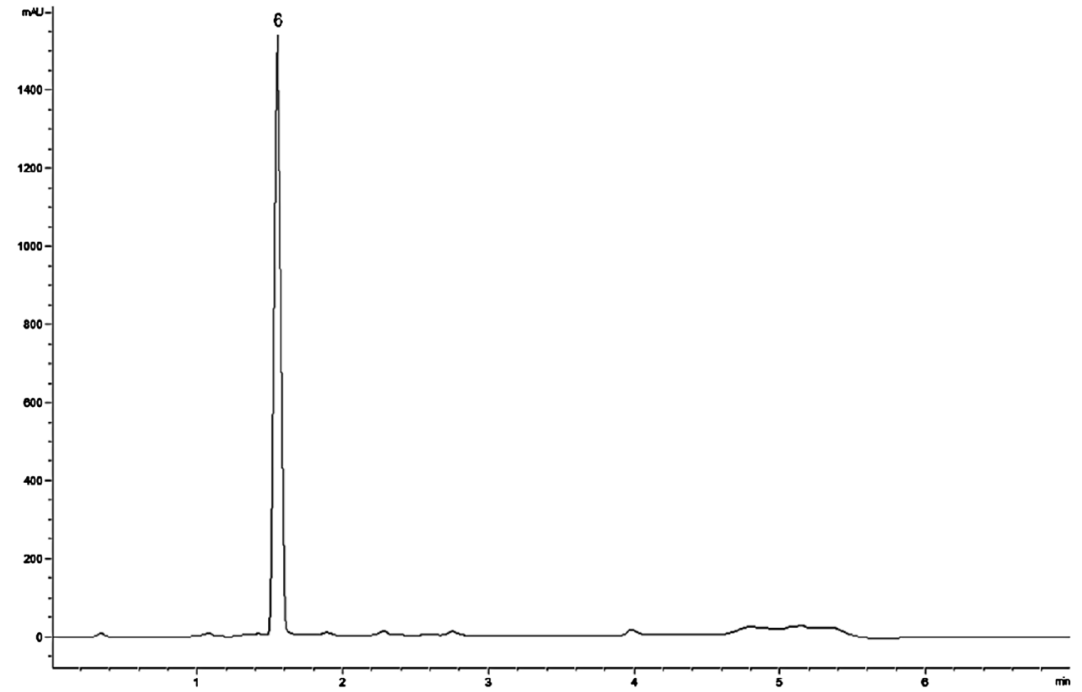

Fig. 5 (See legend on next page.) 
(See figure on previous page.)

Fig. 5 a-c Chromatograms of polyphenolic standards (a), methanol seed extract of T. indica (b) and fraction F3 (c). Individual retention times and peak identification of the polyphenols in the extracts were compared with the chromatogram of a standard mixture of polyphenols analyzed with UHPLC 1290 Infinity LC system. The polyphenols were detected at a wavelength of $280 \mathrm{~nm}$. 1: gallic acid; 2: catechin; 3: procyanidin B2; 4: chlorogenic acid; 5: epicatechin; 6: caffeic acid; 7: vanillic acid; 8: p-coumaric acid; 9: ferulic acid; 10: chloramphenicol; 11: rutin; 12: myricetin; 13: morin; 14: ellagic acid; 15: cinnamic acid; 16: naringenin; 17: quercetin; 18: luteolin; 19: apigenin; 20: isorhamnetin; 21: kaempferol

content contributed to the antioxidant activities of the respective fractions. Various studies have reported positive correlations between polyphenolic content and antioxidant activities of plants $[28,29]$ and results from this study further strengthen the impact of polyphenols as potent antioxidants.

In the treatment of the HepG2 cells, the $\mathrm{IC}_{20}$ concentration of the plant extract and fraction was used in order to keep the concentration low while still maintaining cell viability above $80 \%$. As dietary antioxidants are rapidly metabolized and are usually present in small amounts in the circulation, hence using low concentration would be more significant [30]. Our group had previously reported that the $\mathrm{IC}_{20}$ concentration of the methanol fruit pulp extract of $T$. indica was able to regulate a sizable number of genes involved in different pathways in liver HepG2 cells, further showing that low concentration of the $T$. indica extract was adequate to induce changes in the cells [31].

Treatments of HepG2 cells with the crude extract and fraction F3 increased antioxidant activities of the cells, increased antioxidant enzymes and inhibited ROS production thus inhibited lipid peroxidation. In all instances, fraction F3 showed higher activities than the crude extract. We hypothesize that the crude extract and fraction F3 were able to protect HepG2 cells against oxidative damage via several mechanisms. The increased FRAP and DPPH radical scavenging activities indicated their abilities to act as reducing agents and radical scavengers, thus removing ROS and preventing oxidative damage. Furthermore, the increased antioxidant enzyme activities indicated increased capacity of the cells to convert free radicals into non-reactive forms. This was reflected in the reduced levels of lipid peroxidation.

Lipid peroxidation is an important factor in the pathologies of many diseases associated with oxidative stress [32]. The reaction of ROS such as $\mathrm{H}_{2} \mathrm{O}_{2}$ with the double bonds of polyunsaturated fatty acids during oxidative damage yield lipid hydroperoxides, which can cause membrane dysfunction. Lipid hydroperoxides can be further metabolized to produce a variety of aldehydes, including malondialdehyde (MDA) and 4-hydroxynonenal (4-HNE) [33, 34]. MDA appears to be the most mutagenic product of lipid peroxidation, whereas 4-HNE is the most toxic one [35]. Both MDA and 4-HNE are biomarkers for oxidative stress and are found to be elevated in various diseases thought to be related to oxidative damage [36]. Hence they are widely used as indexes of lipid peroxidation [37]. It has been reported that male broilers fed with polyphenols extracted from $T$. indica seed coat had lower MDA levels [38]. In addition, $T$. indica seed coat was also reported to attenuate lipid peroxidation in $\mathrm{H}_{2} \mathrm{O}_{2}$-induced human foreskin fibroblast cells [39]. Treatment with the crude extract and particularly fraction F3 caused significant inhibition of lipid

Table 3 Identification and quantification of polyphenols in the crude methanol seed extract and fraction F3 of T. indica

\begin{tabular}{|c|c|c|c|c|}
\hline Peak number & Compounds & $R^{2}$ & Recovery (\%) & Polyphenol content ( $\mu \mathrm{g} / \mathrm{g}$ crude extract) \\
\hline \multicolumn{5}{|l|}{ Crude extract } \\
\hline 2 & Catechin & 0.9993 & 101.03 & $46.92 \pm 1.86$ \\
\hline 3 & Procyanidin B2 & 0.9963 & 101.44 & $516.95 \pm 4.64$ \\
\hline 6 & Caffeic acid & 0.9949 & 100.24 & $446.58 \pm 2.35$ \\
\hline 9 & Ferulic acid & 0.9933 & 101.45 & $35.82 \pm 1.28$ \\
\hline 10 & Chloramphenicol & 0.9980 & 101.98 & $27.10 \pm 1.33$ \\
\hline 12 & Myricetin & 0.9921 & 101.52 & $298.69 \pm 2.07$ \\
\hline 13 & Morin & 0.9911 & 101.77 & $70.98 \pm 1.35$ \\
\hline 17 & Quercetin & 0.9968 & 98.06 & $11.48 \pm 0.69$ \\
\hline 19 & Apigenin & 0.9997 & 100.25 & $115.00 \pm 2.69$ \\
\hline 21 & Kaempferol & 0.9977 & 98.36 & $111.41 \pm 1.72$ \\
\hline \multicolumn{5}{|l|}{ Fraction F3 } \\
\hline 6 & Caffeic acid & 0.9949 & 100.24 & $451.03 \pm 2.84$ \\
\hline
\end{tabular}




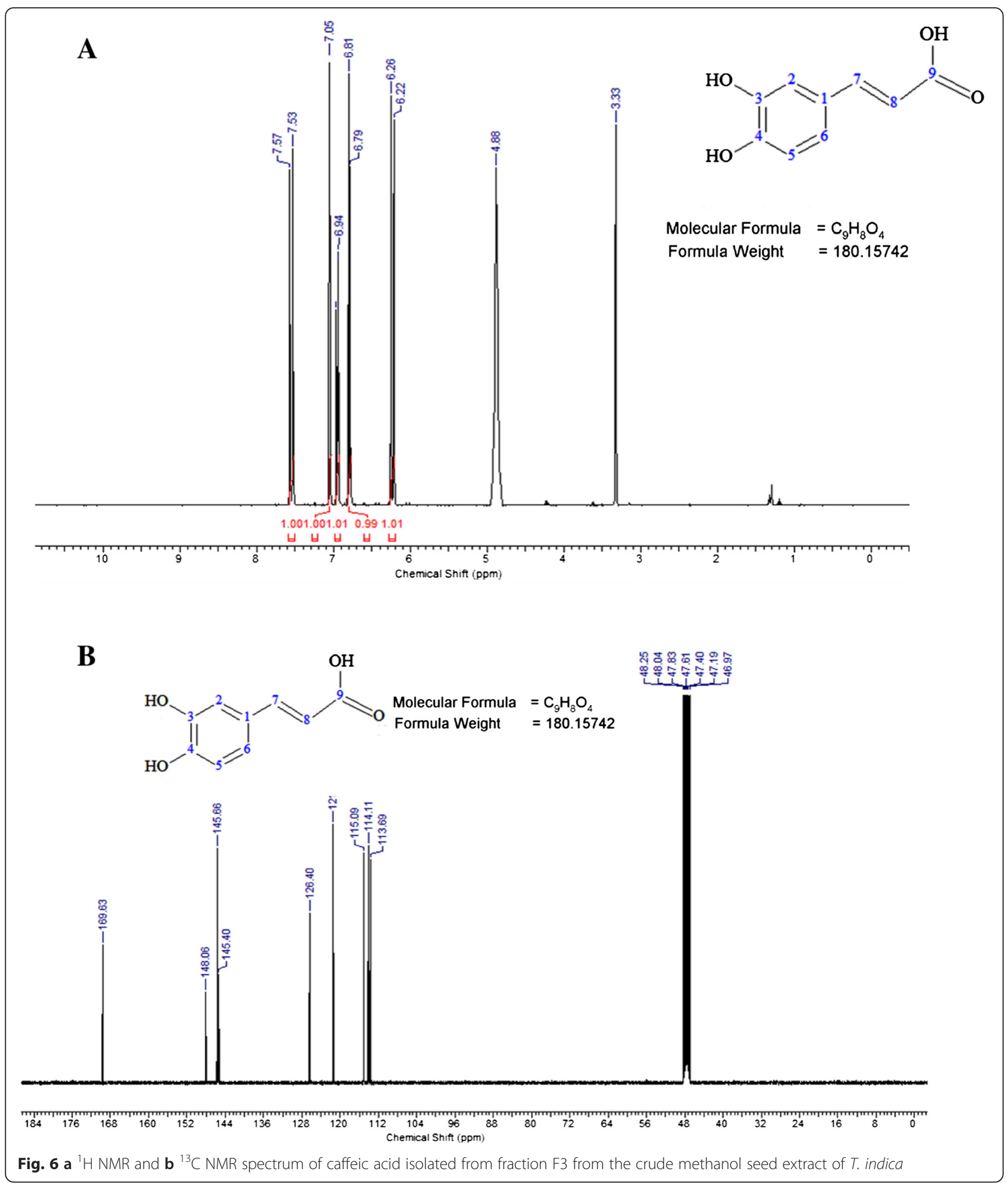

peroxidation in oxidative damage-induced HepG2 cells. Hence, it can be speculated that the crude seed extract and fraction F3 mediated protection of HepG2 cells against toxicity towards $\mathrm{H}_{2} \mathrm{O}_{2}$ by the inhibition of hepatic lipid peroxidation, supporting previous reports.
SOD, GPx and CAT are the primary antioxidant enzymes in mammalian cells that are important in oxygen metabolizing cells. SOD catalyzes the dismutation of superoxide anion radicals into $\mathrm{H}_{2} \mathrm{O}_{2}$ and water, while CAT and GPx convert $\mathrm{H}_{2} \mathrm{O}_{2}$ into water, reducing the 
amounts of $\mathrm{H}_{2} \mathrm{O}_{2}$, hence protecting the cells against oxidative damage. The increased antioxidant enzyme activities, together with increased FRAP and DPPH radical scavenging activities, could have caused lower production of ROS, leading to inhibition of lipid peroxidation, which was reflected in the lower MDA and HNE amounts.

Changes in the activity of antioxidant enzymes can be considered as biomarkers of the antioxidant response [40] as they play an essential role in the defense against oxidative stress. Treatment with the crude extract and fraction F3 enhanced the activity of the antioxidant enzymes in HepG2 cells, as a protective mechanism to counter the increasing generation of ROS induced by $\mathrm{H}_{2} \mathrm{O}_{2}$. Previous studies reported that plant polyphenols including caffeic acid [41] and quercetin [42] induced the activities of SOD, GPx and CAT and strongly inhibited the generation of ROS in the oxidative stressinduced HepG2 cells, thus preventing or delaying conditions which favor oxidative stress in the cells.

In the present study, fraction F3 showed more pronounce effects than the crude extract in antioxidant potency including in enhancing antioxidant enzymes. The defense against ROS particularly in the liver is mediated by the transcription factor Nuclear factor E2-related factor 2 (NRF2). NRF2 activates and induces antioxidant responsive element (ARE) which results in the coordinated activation of genes that encode phase II detoxification and antioxidant enzyme expression [43]. Previous studies reported that phenolic acids including caffeic acid activated NRF2-ARE-mediated signaling in HepG2 cells by inducing the expression of genes encoding phase II drug metabolism/detoxification and anti-oxidative stress enzymes including SOD, CAT and GPx [44]. We speculated that bioactive compoundsin fraction F3 including caffeic acid could regulate the expression of antioxidant enzymes mediated by NRF2-ARE.

In this study, the multitude of polyphenolic compounds detected in the seed extracts of $T$. indica likely contributed to the high antioxidant activities. In fact, Siddhuraju (2007) had reported the potent antioxidant activities of the seed coat of T. indica [45]. Analyses for polyphenolic compounds in an earlier study reported the presence of mainly procyanidins in the seeds of $T$. indica, including the trimer, tetramer, hexamer and pentamer forms, procyanidin B2 and (-)-epicatechin [46]. Our analyses detected the additional presence of catechin, caffeic acid, ferrulic acid, chloramphenicol, myricetin, morin, quercetin, apigenin and kaempferol, which have not been previously reported. Procyanidin B2 is the major polyphenolic compound in the seed extract and it has several biological properties including antioxidant activity $[47,48]$ and anti-tumor effect [49]. As an antioxidant, procyanidin $\mathrm{B} 2$ can inhibit the generation of highly reactive species such as the hydroxyl radicals and chelates Fe (II) ions [50].

Fractionation of the methanol seed extract led to enhancement of their antioxidant potency as well as isolation of the bioactive compound. Previous studies have indicated the beneficial effect of fractionation in concentrating polyphenolic compounds, producing fractions with more potent antioxidant activities [51, 52]. UHPLC and NMR analyses of fraction F3 identified caffeic acid as the bioactive compound and this is the first report on its presence in $T$. indica seed. Caffeic acid, on its own can function as a potent antioxidant, and did not require the synergistic effects of the multitude of polyphenols present in the crude extracts. In addition to antioxidants, several biological activities have been attributed to caffeic acid including anti-inflammatory [52], antibacterial [53] and anti-carcinogenic effects [54]. The beneficial antioxidant properties of caffeic acid have been demonstrated in both in vivo and in vitro analyses involving various mechanisms including radical scavenging, metal ion chelation, and inhibitory actions on enzymes that induce free radical and lipid hydroperoxide formation [55]. The structural feature responsible for the antioxidant and radical scavenging activity of caffeic acid is the ortho-dihydroxyl group in the catechol ring. The presence of the electron-donating hydroxyl group at the ortho-position also lowers the $\mathrm{O}-\mathrm{H}$ bond dissociation enthalpy and increases the rate of $\mathrm{H}$-atom transfer to peroxyl radicals [56]. The unsaturated 2,3-double bond of the side chain also maximizes the stabilization of the polyphenolic radical [57].

\section{Conclusions}

In this study, we identified the presence of ten polyphenolic compounds in the methanol seed extract of $T$. indica with seven of them reported here for the first time. Caffeic acid was identified as the most active compound in regards to antioxidant activities and was able to protect HepG2 cells against lipid peroxidation, possibly by acting as reducing agents, radical scavengers and by increasing activities of antioxidant enzymes. The seeds of $T$. indica have great potential for further research particularly in the area of oxidative stress and oxidative damage-related diseases. In addition, the high polyphenolic content and antioxidant activity of the seed makes them attractive ingredients in commerciallyproduced food-based products.

\footnotetext{
Competing interests

The authors declare that they have no competing interest.
}

\section{Authors' contributions}

NR carried out the collection and extraction of plant materials, phytochemical analyses including antioxidant, column chromatography and UHPLC, and drafted the manuscript; SMJ participated in the design and general

coordination of the study, evaluated the data and edited the manuscript; AA 
carried out the NMR analyses and edited the manuscript; NSFR participated in UHPLC analyses; AAA made substantial contribution to conception and design, participated in general coordination of the study, and revising the manuscript critically for important intellectual content. All authors read and approved the final manuscript.

\section{Acknowledgements}

We would like to thank Lim Moo Eng, Rahimah Ismail, Azizah Ahmad, Arif Fakhrie Johari, Norzalida Zakaria and Nordin Mohamed for their technical expertise. This research project was funded by research grants from the Ministry of Education, Malaysia (FP015-2013B) and University of Malaya, Kuala Lumpur, Malaysia (PV116-2012A and H-20001-00-E000009).

\section{Author details}

${ }^{1}$ Department of Molecular Medicine, Faculty of Medicine, University of Malaya, 50603 Kuala Lumpur, Malaysia. ²Department of Chemistry, Faculty of Science, University of Malaya, 50603 Kuala Lumpur, Malaysia.

\section{Received: 6 July 2015 Accepted: 9 December 2015}

Published online: 18 December 2015

\section{References}

1. Halliwell B. Free radicals, antioxidants, and human disease: curiosity, cause, or consequence? Lancet. 1994;344(8924):721-4.

2. Velioglu YS, Mazza G, Gao L, Oomah BD. Antioxidant activity and total phenolics in selected fruits, vegetables, and grain products. J Agric Food Chem. 1998;46(10):4113-7.

3. Covas Ml, Nyyssonen K, Poulsen HE, Kaikkonen J, Zunft HJ, Kiesewetter H, et al. The effect of polyphenols in olive oil on heart disease risk factors: a randomized trial. Ann Intern Med. 2006;145(5):333-41.

4. Singh I, Mok M, Christensen AM, Turner AH, Hawley JA. The effects of polyphenols in olive leaves on platelet function. Nutr Metab Cardiovasc Dis. 2008;18(2):127-32.

5. Morton J. Tamarind. In: Morton JF, editor. Fruits of warm climates. Miami, USA: Florida Flair Books; 1987. p. 115-21.

6. El-Siddig K, Gunasena HPM, Prasa BA, Pushpakumara DKNG, Ramana KVR, Vijayanand $\mathrm{P}$, et al. Tamarind - Tamarindus indica L. Fruits for the future 1. Southampton, UK: Southampton Centre for Underutilized Crops; 2006.

7. Van der Stege C, Prehsler S, Hartl A, Vogl CR. Tamarind (Tamarindus indica L. ) in the traditional West African diet: not just a famine food. Fruits. 2011; 66(03):171-85.

8. Tsuda T, Makino Y, Kato H, Osawa T, Kawakishi S. Screening for antioxidative activity of edible pulses. Biosci Biotechnol Biochem. 1993;57(9):1606-8.

9. Mishra A, Malhotra AV. Tamarind xyloglucan: a polysaccharide with versatile application potential. J Mater Chem. 2009;19(45):8528-36.

10. Semenzato A, Costantini A, Baratto G. Green polymers in personal care products: rheological properties of tamarind seed polysaccharide. Cosmetics. 2014;2(1):1.

11. Marathe R, Annapure U, Singhal R, Kulkarni P. Gelling behaviour of polyose from tamarind kernel polysaccharide. Food Hydrocolloids. 2002;16(5):423-6.

12. Maiti R, Das UK, Ghosh D. Attenuation of hyperglycemia and hyperlipidemia in streptozotocin-induced diabetic rats by aqueous extract of seed of Tamarindus indica. Biol Pharm Bull. 2005;28(7):1172-6.

13. Razali N, Mat-Junit S, Abdul-Muthalib AF, Subramaniam S, Abdul-Aziz A. Effects of various solvents on the extraction of antioxidant phenolics from the leaves, seeds, veins and skins of Tamarindus indica L. Food Chem. 2012; 131(2):441-8.

14. Singleton VL, Rossi JA. Colorimetry of Total Phenolics with Phosphomolybdic-Phosphotungstic Acid Reagents. Am J Enol Vitic. 1965; 16(3):144-58.

15. Benzie IFF, Strain JJ. The Ferric Reducing Ability of Plasma (FRAP) as a Measure of "Antioxidant Power": The FRAP Assay. Anal Biochem. 1996; 239(1):70-6

16. Braca A, De Tommasi N, Di Bari L, Pizza C, Politi M, Morelli I. Antioxidant Principles from Bauhinia tarapotensis. J Nat Prod. 2001;64(7):892-5.

17. Hasiah A, Ghazali A, Weber J, Velu S, Thomas N, Inayat Hussain S. Cytotoxic and antioxidant effects of methoxylated stilbene analogues on HepG2 hepatoma and Chang liver cells: Implications for structure activity relationship. Hum Exp Toxicol. 2011;30(2):138-44.

18. Inal ME, Kanbak G, Sunal E. Antioxidant enzyme activities and malondialdehyde levels related to aging. Clin Chim Acta. 2001;305(1-2):75-80.
19. Razali N, Aziz AA, Lim CY, Junit SM. Investigation into the effects of antioxidant-rich extract of Tamarindus indica leaf on antioxidant enzyme activities, oxidative stress and gene expression profiles in HepG2 cells. Peer J. 2015;3, e1292.

20. Marabini L, Frigerio S, Chiesara E, Radice S. Toxicity evaluation of surface water treated with different disinfectants in HepG2 cells. Water Res. 2006; 40(2):267-72

21. Aziz AA, Edwards CA, Lean ME, Crozier A. Absorption and excretion of conjugated flavonols, including quercetin-4'-O-beta-glucoside and isorhamnetin-4'-O-beta-glucoside by human volunteers after the consumption of onions. Free Radic Res. 1998;29(3):257-69.

22. Kwan EE, Huang SG. Structural elucidation with NMR spectroscopy: practical strategies for organic chemists. European J Org Chem. 2008;2008(16):2671-88.

23. Gurib-Fakim A. Medicinal plants: Traditions of yesterday and drugs of tomorrow. Mol Aspects Med. 2006;27(1):1-93.

24. Schramm DD, German JB. Potential effects of flavonoids on the etiology of vascular disease. J Nutr Biochem. 1998;9(10):560-6.

25. Formica JV, Regelson W. Review of the biology of quercetin and related bioflavonoids. Food Chem Toxicol. 1995;33(12):1061-80.

26. Razali N, Razab R, Junit SM, Aziz AA. Radical scavenging and reducing properties of extracts of cashew shoots (Anacardium occidentale). Food Chem. 2008;111(1):38-44

27. Rice-Evans CA, Miller NJ. Antioxidant activities of flavonoids as bioactive components of food. Biochem Soc Trans. 1996;24(3):790-5.

28. Cai Y, Luo Q, Sun M, Corke H. Antioxidant activity and phenolic compounds of 112 traditional Chinese medicinal plants associated with anticancer. Life Sci. 2004;74(17):2157-84

29. Razab R, Abdul-Aziz A. Antioxidants from tropical herbs. Nat Prod Commun 2010;5(3):441-5

30. Holiman PCH, Hertog MGL, Katan MB. Analysis and health effects of flavonoids. Food Chem. 1996;57(1):43-6.

31. Razali N, Aziz AA, Junit SM. Gene expression profiles in human HepG2 cells treated with extracts of the Tamarindus indica fruit pulp. Genes Nutr. 2010; 5(4):331-41.

32. Niki E. Lipid peroxidation: Physiological levels and dual biological effects. Free Radic Biol Med. 2009:47(5):469-84

33. Brattin WJ, Glende Jr EA, Recknagel RO. Pathological mechanisms in carbon tetrachloride hepatotoxicity. J Free Radic Biol Med. 1985:1(1):27-38.

34. Spickett CM. The lipid peroxidation product 4-hydroxy-2-nonenal: Advances in chemistry and analysis. Redox Biol. 2013;1:145-52.

35. Esterbauer $H$, Eckl P, Ortner A. Possible mutagens derived from lipids and lipid precursors. Mutat Res. 1990;238(3):223-33.

36. Zhong H, Yin H. Role of lipid peroxidation derived 4-hydroxynonenal (4HNE) in cancer: Focusing on mitochondria. Redox Biol. 2015;4:193-9.

37. Zhang QH, Wu CF, Duan L, Yang JY. Protective effects of ginsenoside Rg(3) against cyclophosphamide-induced DNA damage and cell apoptosis in mice. Arch Toxicol. 2008:82(2):117-23.

38. Aengwanich W, Suttajit M. Effect of polyphenols extracted from Tamarind (Tamarindus indica L.) seed coat on physiological changes, heterophil/ lymphocyte ratio, oxidative stress and body weight of broilers (Gallus domesticus) under chronic heat stress. Anim Sci J. 2010;81(2):264-70.

39. Nakchat $O$, Nalinratana N, Meksuriyen D, Pongsamart S. Tamarind seed coat extract restores reactive oxygen species through attenuation of glutathione level and antioxidant enzyme expression in human skin fibroblasts in response to oxidative stress. Asian Pac J Trop Biomed. 2014;4(5):379-85.

40. Sies H. Strategies of antioxidant defense. Eur J Biochem. 1993;215(2):213-9.

41. Yang S-Y, Hong C-O, Lee GP, Kim C-T, Lee K-W. The hepatoprotection of caffeic acid and rosmarinic acid, major compounds of Perilla frutescens, against t-BHP-induced oxidative liver damage. Food Chem Toxicol. 2013; 55:92-9.

42. Alía M, Ramos S, Mateos R, Granado-Serrano AB, Bravo L, Goya L. Quercetin protects human hepatoma HepG2 against oxidative stress induced by tertbutyl hydroperoxide. Toxicol Appl Pharmacol. 2006;212(2):110-8.

43. Lee Y-J, Lee DM, Lee S-H. Nrf2 Expression and Apoptosis in Quercetintreated Malignant Mesothelioma Cells. Mol Cells. 2015;38(5):416-25.

44. Kim J-K, Jang H-D. Nrf2-Mediated HO-1 Induction Coupled with the ERK Signaling Pathway Contributes to Indirect Antioxidant Capacity of Caffeic Acid Phenethyl Ester in HepG2 Cells. Int J Mol Sci. 2014;15(7):12149-65.

45. Siddhuraju P. Antioxidant activity of polyphenolic compounds extracted from defatted raw and dry heated Tamarindus indica seed coat. LWT - Food Science and Technology. 2007:40(6):982-90. 
46. Sudjaroen Y, Haubner R, Wurtele G, Hull WE, Erben G, Spiegelhalder B, et al. Isolation and structure elucidation of phenolic antioxidants from Tamarind (Tamarindus indica L.) seeds and pericarp. Food Chem Toxicol. 2005;43(11): 1673-82.

47. Baba S, Osakabe N, Natsume M, Terao J. Absorption and urinary excretion of procyanidin B2 [epicatechin-(4ß-8)-epicatechin] in rats. Free Radic Biol Med. 2002;33(1):142-8.

48. Cho ES, Jang YJ, Kang NJ, Hwang MK, Kim YT, Lee KW, et al. Cocoa procyanidins attenuate 4-hydroxynonenal-induced apoptosis of $\mathrm{PC} 12$ cells by directly inhibiting mitogen-activated protein kinase kinase 4 activity. Free Radic Biol Med. 2009;46(10):1319-27.

49. Gali HU, Perchellet EM, Gao XM, Karchesy JJ, Perchellet JP. Comparison of the inhibitory effects of monomeric, dimeric, and trimeric procyanidins on the biochemical markers of skin tumor promotion in mouse epidermis in vivo. Planta Med. 1994;60(3):235-9.

50. Sakano K, Mizutani M, Murata M, Oikawa S, Hiraku Y, Kawanishi S. Procyanidin B2 has anti- and pro-oxidant effects on metal-mediated DNA damage. Free Radic Biol Med. 2005;39(8):1041-9.

51. Reddy N, Navanesan S, Sinniah S, Wahab N, Sim K. Phenolic content, antioxidant effect and cytotoxic activity of Leea indica leaves. BMC Complement Altern Med. 2012;12(1):128.

52. da Cunha FM, Duma D, Assreuy J, Buzzi FC, Niero R, Campos MM, et al. Caffeic acid derivatives: in vitro and in vivo anti-inflammatory properties. Free Radic Res. 2004;38(11):1241-53.

53. Stojković D, Petrović J, Soković M, Glamočlija J, Kukić-Marković J, Petrović S. In situ antioxidant and antimicrobial activities of naturally occurring caffeic acid, p-coumaric acid and rutin, using food systems. J Sci Food Agric. 2013; 93(13):3205-8.

54. Prasad NR, Karthikeyan A, Karthikeyan S, Reddy BV. Inhibitory effect of caffeic acid on cancer cell proliferation by oxidative mechanism in human HT-1080 fibrosarcoma cell line. Mol Cell Biochem. 2011;349(1-2):11-9.

55. Son S, Lewis BA. Free radical scavenging and antioxidative activity of caffeic acid amide and ester analogues: structure - activity relationship. J Agric Food Chem. 2002:50(3):468-72.

56. Lucarini M, Pedulli GF, Cipollone M. Bond dissociation enthalpy of.alphatocopherol and other phenolic antioxidants. J Org Chem. 1994;59(17):5063-70.

57. Rice-Evans CA, Miller NJ, Paganga G. Structure-antioxidant activity relationships of flavonoids and phenolic acids. Free Radic Biol Med. 1996; 20(7):933-56.

\section{Submit your next manuscript to BioMed Central and we will help you at every step:}

- We accept pre-submission inquiries

- Our selector tool helps you to find the most relevant journal

- We provide round the clock customer support

- Convenient online submission

- Thorough peer review

- Inclusion in PubMed and all major indexing services

- Maximum visibility for your research

Submit your manuscript at www.biomedcentral.com/submit
Biomed Central 